\title{
Cultivation of Creative Thinking Ability of Students in English Class
}

\author{
Ge Liür, a Hongwei Shi ${ }^{2, b}$ and Yandong $\mathrm{Qu}^{2, \mathrm{c}}$ \\ ${ }^{1}$ Bohai University, 121003, Jinzhou, China \\ ${ }^{2}$ Center Primary School of Hanmaying, Chengde 068151, China; \\ ${ }^{3}$ Liaoning University of Technology, Jinzhou 121001, China. \\ alg781115@163.com, bhongwei10@126.com, cplxfeng2009@sohu.com
}

Keywords: Teaching reform, creative thinking ability, classroom teaching, interactive teaching

\begin{abstract}
Creative thinking, which has a close relationship with language and language learning, is the inner requirement of improving people's cognitive ability. This paper mainly discussed about the methods on how to cultivate creative thinking ability of students and improve college English teaching efficiency from the following aspects: highlighting fostering creative thinking of students in the objectives of classroom teaching and well-designed curriculum system; promoting cooperation and interaction, and expanding the innovative thinking space of students; encouraging timely questioning and enhancing students' innovative thinking depth; charring out positive evaluation and strengthening the students' creative thinking; cultivation of innovative thinking ability visa inquiry learning method; creating a classroom atmosphere that promotes risk-taking and speculative thinking.
\end{abstract}

\section{Introduction}

The Ministry of Education of China initiated the Teaching Quality and Reform Plan (TQRP) in 2003[1]. The teaching reform of English in Chinese Universities was listed as an important content of TQRP to improve the teaching effect and to promote the innovation of students [2-4]. After more than 10 years of reform, English teaching reform in China has made significant progress, such as the development of software system and network of English teaching [5-6]; launching the CET4ICET6 exam reform plan. Moreover, the curriculum design and teaching modes have also been improved [7].

Creative thinking, which has a close relationship with language and language learning, is the inner requirement of improving people's cognitive ability. English teaching effects has the positive relationship with cultivation of creative thinking ability of students [5]. In recent years, more and more academic experts began to focus on the conditions of teachers' creative thinking skill. They advocate that, when preparing the curriculum, teachers should attach to the importance of developing their own skills. Some researchers probed into its training approaches, such as case study, and network discussion. The training on students' creative thinking skill through college English teaching and learning, however, hasn't been further explored and practiced. The paper mainly discusses the methods to train and develop creative thinking abilities of students in English classroom.

\section{Disadvantages of fostering creative thinking ability in English classroom}

There are many disadvantages of fostering creative thinking abilities in the current college English classroom. It is associated with both the subjective factors for teachers and the objective reasons for students. The main disadvantages are as follows:

(1) Unclear objective of English classroom and lack of innovation consciousness of students

Leading the trend of English classroom, the objective of teaching plays an important role in college English classroom and it is also the important yardstick of measuring teaching effect. Objective of English classroom is to study the learning situation that learners should achieve in English classroom, or to meet the requirements of learning. Determining teaching target accurately is also the guarantee of the effectiveness of English classroom. However, teachers still place themselves 
in the center positions of classroom teaching and blindly script to speak some textbooks mentioned linguistic knowledge. Objectives of English classroom don't enunciate how to foster creative thinking ability of students. The knowledge structure of English language is looked on as the goal of classroom teaching, which results in students no understanding what I should learn, what is the focus, and what learning objectives should be achieved. Teachers often neglect the positions and feeling of students in the classroom teaching, which give rise to the lack of innovation consciousness of students.

(2) Low quality of professional knowledge and limited creative thinking ability of teachers

English has the particularity of its own. Therefore, teachers should have high quality of English knowledge, besides the qualities of ordinary teachers. But some teachers, especially young teachers couldn't strengthen the professional knowledge due to the limitation of their own teaching experience. They couldn't improve their own teaching quality, which make students lose the attraction of English classroom teaching. The actual effect of English classroom teaching couldn't be obtained. Moreover, most of English teachers don't have abundant creative thinking abilities, which are harmful to cultivation of innovation consciousness of students.

(3) Lack of interactions and single teaching method used in English language class

The interactions of teachers and students, students and students should not be ignored in college English classroom teaching. Teachers often abandon the interactions between teacher and students in traditional classroom teaching, which caused the boredom of traditional classroom teaching mode. Students prefer to learn creatively by exploring, questioning, experimenting, manipulating, listening, and testing. Educational institutions insisting that students should learn by authority. Authoritarian systems of learning lack the properties of flexibility, originality, elaboration, uniqueness, novelty, fluency, and purposiveness of creative thinking. Students can only accept the contents of teacher's lecture.

How to Foster creative thinking ability in English class

(1) Highlighting fostering creative thinking of students and well-designed curriculum system

Teachers in class are required to train students' learning capacity, to develop students' thinking ability, to improve students' learning efficiency, and to teach explicitly how to think the tasks. If teachers can't design the teaching curriculum well, and well combine their actual English teaching, it is impossible to obtain the success of class teaching. There have higher requirements for English teaching with the deepening of English teaching reform. Teachers should make full use of teaching resources in network and multimedia, and make students constantly explore the enthusiasm of English study.

(2) Promoting cooperation and interaction, and expanding students' innovative thinking space

Teaching resources are all the teaching materials used in the teaching process. They usually includes English textbooks, guidance materials, physical education and computer software. New English textbook can provide a lot of information for learning English to students, teaching materials in the textbook are static, however. If teachers can try their best to make the static text move, namely, and use multimedia courseware or other media, such as movies, and slides, then the information capacity of class will be increased, which can greatly improve teaching efficiency. In order to further expand students' creative thinking space, the interaction and cooperation methods should also be adopted in class. That is, the collective groups of students make courseware in cooperation in the hands and brains under the guidance of teachers and three-dimensional interactive network thinking could be formed. It allows teachers to make full use of the additional methods to their traditional teaching, such as problem-solving activities, critical-thinking exercises, collaborative learning, and independent study [8]. Teachers should also strengthen students to explore the knowledge of interest, and create good learning environments to achieve the expected teaching effects in English class. Teachers can foster the creative thinking ability of students by stimulating active learning and get the supported help from the students' experiences.

(3) Enhancing students' innovative thinking depth 
When teaching in English class, attention should be paid to designing all kinds of questions from multi angles and multi ranges. Student are enabled to not only stay in the understanding contents, but also combine with the learning knowledge to explore, to create, and to enhance their innovative thinking depth and to cultivate the ability of innovation. A variety of thinking training methods should be also used in the discourse teaching and students are encouraged to reprocess the text content according to the language materials of textbooks from thinking of different aspects and different angles. For example, when teaching unit 3 "why do you like koala bears?”, according to the text of bold question, I often ask many questions, such as: why do people like animals such as' pandas' in China? What can be done for wild animal protection? Do you have any suggestions for protecting wild animals? Therefore, accompanying students' thinking in the wings of imagination, the innovative thinking depth of students is enhanced. It raised higher requirements for teachers to lead students to improve college English using self-perfection, self-development, and self-development.

\section{(4) Charring out positive evaluation and strengthening the students' creative thinking} ability

Teacher's trust and encouragement influence directly the intellectual curiosity and creative thinking consciousnes of students. In the teaching, students often have some strange and eccentric ideas. If given harsh criticism, blame or censure, students' misty, and fragmentary will be suppressed. It will hinder the development of students' creative thinking ability. Therefore, students should be placed in relaxed and harmonious environments. Teachers should make a positive evaluation on the students' learning behaviors and learning outcomes, encourage the creative thinking of students. If students make mistakes in the evaluation, I don't say "no", but say "thank you”, and "please think it over for the wrong operation". Meanwhile, students with different levels have different requirements. To excellent students, strict and high requirements of evaluation are also given. If teachers can pay more attention to giving students positive evaluation, students can think and innovate in relaxed teaching environments. The creative thinking ability of students could be improved.

\section{(5) Cultivation of innovative thinking ability visa inquiry learning method}

Recently, inquiry learning has been the hot spot of education reform of English. As a kind of needs from their individual development, understanding of law of training the new learning way of students' innovation ability and innovative talents training mode can provide new train of thought to cultivate the creative thinking ability of students. Yuan also pointed out: "based on the interests, from nature, society, their own life and research topics, research learning is that students apply knowledge and solve the problem of learning activities under the guidance of teachers". Creative thinking ability is thinking process of new things and creates new methods to solve new problems found in the existing experience.

The biggest characteristic of research study is breaking with the traditional teaching mode. It requires teachers to play attention to the main role of students, to break the closed state of classroom teaching by creating a similar scenario to scientific research. Students are requied to learn as an important carrier and take the initiative to understand and accept the teaching content, excavate the potential of learning, collect the active learning of informationion, acquire knowledge and appliy knowledge by exploration, practice, and experience of their own. Moreover, the premise and foundation of cultivating the innovative thinking ability is that the students should accumulate more knowledge. Therefore, the study of learning is not only a process of knowledge construction, a constructive learning process, but a process of cultivating innovative personality, innovative ability and cooperative spirit of students.

\section{(6) Promotes risk-taking and speculative thinking}

Adopting the method "interventions" to foster the creative thinking of students, in order to stimulate creative thinking, it is necessary for the teachers to create the classroom conditions and to encourage students to think intuitively and spontaneously, and to use inquiry-discovery teaching techniques. Students are also encouraged to make educated guesses on the basis of the available evidence, data and information they have. A friendly, supportive and non-threatening classroom atmosphere has a positive impact on students' motivation and language performance in their minds. A 
positive climate for learning has been identified by many educationalists as a critical factor in effective learning.

Within the framework of project-based learning, students do not follow strict guidelines, but are invited to improvise, come up with solutions to the problems they encounter, to find alternative ways to fulfill a task, to cooperate, to take risks, to develop effective communicative skills, to evaluate themselves, in other words, promote creative thinking.

\section{Conclusions}

The reform of college English class is a systematic reform, which involves the development of English teachers' professional development and the improvement of students' autonomous learning ability. As an important part of thinking activity, creative thinking is the inner requirement of improving people's cognitive ability, and it has a close relationship with language and language learning. Combined with the research of English teaching reform in class and some existing problems in the current English classroom teaching, this paper mainly discussed about the approach and methods on how to cultivate creative thinking ability of students in class and improve the college English teaching efficiency from the following aspects: highlighting fostering creative thinking of students in the objectives of classroom teaching and well-designed curriculum system; promoting cooperation and interaction, and expanding the innovative thinking space of students; encouraging timely questioning and enhancing students' innovative thinking depth; charring out positive evaluation and strengthening the students' creative thinking; cultivation of innovative thinking ability visa inquiry learning method; creating a classroom atmosphere that promotes risk-taking and speculative thinking.

\section{Acknowledgments}

This research was financially supported by the Humanities and Social Science Research Project of Education Department of Liaoning Province (No. W2014161).

\section{References}

[1] The Ministry of Education of the People's Republic of China. 2003. Reading the 2003-2007 Plan for Revitalizing Education. Beijing: The Education Science Press.

[2] G. Liu, Thinking of classroom teaching based on the reform of College English Teaching, Journal of Bohai University: Philosophy and Social Sciences, (2013)148-149.

[3] F. Ma, W. Han. A research on "Short-term High-density College English Teaching Mode” on the Basis of Frequency Effects Theory. Shandong Foreign Language Teaching Journal, (1) 2014:63-655.

[4] R. J. Lund, A comparison of second language listening and reading comprehension, The Modern Language Journal, 2 (1991):196-204.

[5] W Li, College English Teaching and Learning through Online Learning Community: Principles and Practices, International Journal of Engineering Research and Development, 7(2013) 25-29.

[6]G. Liu, A Learner Autonomy Model: It's Effect on English as a Second Language Learning. 2nd international conference on complex science management and education science (CSMES 2015), 2015, September 19, Changsha, PP. 328-333.

[7] N McLoughlin, The Creation of a Flexible Curriculum Design and Mode of Delivery in Response to the Effects of Higher Education Policy on the Way we Teach Creative Writing. The International Journal for the Practice and Theory of Creative Writing, 6(2009):124-132.

[8] T Iakovos, Critical and Creative Thinking in the English Language Classroom. International Journal of Humanities and Social Science,1(2011) 82-86. 